\title{
Rx for Reading Detroit: Place-Based Social Justice Pedagogy
}

\author{
Mary-Catherine Harrison \\ University of Detroit Mercy
}

\begin{abstract}
While social justice models of service-learning improve on volunteerism that ignores structural inequality, they often neglect the critical role of local environments in which the service occurs. I argue that a placebased model of service-learning enables a diverse student body to move beyond compassionate service to social justice activism. In 2014, I founded Rx for Reading Detroit, a service-learning program at University of Detroit Mercy that works to promote children's literacy in Detroit. Augmenting critical servicelearning models with a place-based approach offers students a theoretical frame with which to interrogate the complex intersections of geography and justice. Examining Rx for Reading Detroit as a case study in place-based social justice pedagogy, I argue that this paradigm is particularly useful for service-learning in Detroit and other urban contexts because it calls attention to, rather than effaces, the power dynamics inherent with service, including students' diverse relationships to the environments in which they serve.
\end{abstract}

\section{"Talent is spread evenly across America, opportu- nity is not." \\ -Darren Walker, President of the Ford Founda- tion, former Head Start student}

\begin{abstract}
"Frederick Douglass said that literacy is the path from slavery to freedom. There are many kinds of slavery and many kinds of freedom, but reading is still the path."

-Carl Sagan, Scientist and Writer
\end{abstract}

Despite various media outlets touting rebirth, rejuvenation, and renaissance, Detroit remains the most impoverished large city in America. According to the most recent census data, $40.3 \%$ of the city's residents live below the poverty line $\$ 24,008$ for a family of four. The median family income is $\$ 25,764$, approximately half that of the state as a whole (U.S. Census Bureau, 2015 data), while Detroit's unemployment rate is $16.7 \%$, more than twice that of the Michigan average (Michigan League for Public Policy, 2016). 81.6\% percent of Detroit children qualify for free or reduced lunch (Michigan League for Public Policy, 2016) ${ }^{1}$, and $29 \%$ percent of children in the city are living in extreme poverty - less than $50 \%$ of the federal poverty level (Annie E. Casey Foundation, 2015). Moreover, while there has been a surge in development in the city, much of the economic investment is not benefiting its poorest citizens; in many cases it is pushing them further to the margins (Brookings Institute, 2016; Economic Innovation Group, 2016; Reese, Elkers, Sands, \& Vojnovic,
2017; We the People of Detroit, 2016). From 2007 to 2014 Detroit jobs held by Detroit residents actually dropped by $35.5 \%$, while jobs in the city held by individuals living in the suburbs, many of whom are White, increased by $16.6 \%$ (Reese \& Sands, 2017).

Detroit is also the most racially segregated city in America (Logan \& Stults, 2011), an enduring legacy of housing policies that institutionalized racism and exacerbated economic disparities in the region. From 1934 to 1968, the Federal Housing Administration's notorious "redlining" policy undermined minority home ownership and contributed to economic collapse in Black neighborhoods (Silverman, 2005; Sugrue, 2014). Eight Mile Wall, a 6-foot high, half-mile long barrier built between a Black and White neighborhood in northwest Detroit, is only the most tangible artifact of FHA policy. Stark disparities between Detroit and its surrounding suburbs were amplified by White flight in the second half of the $20^{\text {th }}$ century. In 1950, Detroit was $84 \%$ White; by $2010,82.68 \%$ of the population was African-American (U.S. Census Bureau, 2010 data).

The metaphorical and physical boundary of 8 Mile Road continues to reverberate as a dividing line between suburb and city, White and Black, rich and poor. The startling extent of racial segregation in Metro Detroit is made visual in Cable's "Racial Dot Map" (2013), which represents every American with a colored dot indicating their race. ${ }^{2} 8$ Mile is an abrupt slash between green and blue, the colors denoting Black and White individuals; another 
sharp line at Alter Road and Mack Avenue indicates the eastern border of Detroit, where it abuts the wealthy Grosse Pointe area. This kind of racial segregation is inextricably linked with acute income inequality in our region. The median household income in Grosse Pointe, a city that is $93.2 \%$ White, is almost four times that of Detroit. To the north of 8 Mile is Michigan's richest county: $76.5 \%$ of Oakland County's population is White (U.S. Census Bureau, 2014 data).

Economic inequality and racial segregation are both a cause and effect of educational disparities in the Detroit region. In 1974, the Supreme Court Case Milliken v. Bradley blocked busing between majority-Black Detroit public schools and its predominantly White suburban neighbors, severely curtailing the impact of Brown v. Board of Education in Detroit and the nation. By ruling that desegregation could not be ordered across school district lines, the decision effectively reinforced racial and income-based segregation between municipalities, creating incentives for affluent families to move out of low-performing school districts and into wealthier communities and making it even more difficult for low-income families to get a quality education for their children. Today the border between Detroit and Grosse Pointe is the single most economically segregating school district border in the nation (EdBuild, 2016): Detroit's poverty rate is 7.5 times that of its neighbor. Educational disparities between Detroit and suburban school districts are further exacerbated because of the considerable role that property taxes play in school funding. In 20152016, state per-pupil funding was \$9,864 in Grosse Pointe but only $\$ 7,434$ in Detroit Public Schools (Lewis, 2016). As in most of the country, children of color are significantly more likely to live in highpoverty neighborhoods in Michigan (Michigan League for Public Policy, 2016, p. 20). ${ }^{3}$

The consequences of economic and racial segregation are evident at every educational level. On the 2016 M-STEP exam, $19.5 \%$ of Detroit Community Schools $3^{\text {rd }}$ graders were proficient in Language Arts, compared to $81.06 \%$ of Grosse Pointe students and $46 \%$ in the state as a whole (Michigan Department of Education, 2016). Detroit's average SAT score was 757.5, compared to 1126 in Grosse Pointe and a state average of 1001 (Michigan Department of Education). Disparities in K-12 education have had a devastating impact on college access and success. According to data from the National Student Clearinghouse, only $36 \%$ of Detroit Community School students from the class of 2014 were enrolled in college by the following year, compared to $85 \%$ in Grosse Pointe Public Schools and 62.3\% in the state (Mack, 2015). In 2012, only $1.6 \%$ of
Detroit $11^{\text {th }}$ graders were considered college-ready based on their ACT scores (Skillman Foundation, 2012). Only $13.5 \%$ of Detroit adults have Bachelor's degrees (U. S. Census Bureau, 2015 data).

In 2014, I founded Rx for Reading Detroit, a children's literacy initiative sponsored by the University of Detroit Mercy (UDM), where I am a professor of English literature. Staffed by University of Detroit Mercy students and funded by private donations and small grants, the mission of Rx for Reading Detroit is to expand access to high-quality children's books in Detroit and support low-income families in reading with their children. ${ }^{4}$ To date we have distributed 70,000 children's books in partnership with community organizations that serve children and teens, including low-income health, dental, and WIC clinics, Head Start programs, homeless shelters, community centers, churches, public libraries, and juvenile justice facilities. Over 150 undergraduates have participated in a range of capacities: students collect, sort, and distribute donated books; establish and maintain Rx for Reading Detroit free libraries across the city; read with local preschoolers and elementary students; and distribute books at schools and community events. ${ }^{5}$

In this paper I examine Rx for Reading Detroit as a case study in what I call placed-based social justice pedagogy. Combining the two foci of social justice and place, I argue, is a useful tool in moving a diverse group of students beyond volunteerism toward service that interrogates the systemic and interrelated causes of inequality. After discussing why an emphasis on local environments is an essential addition to critical service-learning models (Mitchell, 2008), I examine its particular significance for service-learning in Detroit and other urban environments marked by profound economic and racial disparities. To recognize and confront the "opportunity gap" in our region, students must first identify the broad range of environmental barriers to justice, including the dearth of age-appropriate reading material in low-income neighborhoods. Place-based social justice pedagogy can also help students from diverse backgrounds critically examine their own relationships with geography, justice, and structural privilege. I discuss how we have prioritized local environments in the work of Rx for Reading Detroit and share classroom strategies for analyzing the relationship between place, power, and perspective, including in my home discipline of literary studies.

\section{Critical Service-Learning}

As scholars of service-learning have long recognized, it is fairly simple to affix acts of community- 
engaged service to college coursework. It is much more difficult to scaffold learning such that students do not merely perform acts of service but develop a critical awareness of structural obstacles to equality and justice and work to dismantle intersecting forms of economic, racial, and gender oppression. Without an adequate framework for investigation and reflection, students can perform acts of service but remain unaware of the structures of power and privilege that make service necessary. Servicelearning also risks replicating Freire's (2000) "false charity," upholding oppression by ameliorating symptoms of poverty and racism and leaving untouched their underlying causes. In its most pernicious form, service-learning constructs the student volunteer as beneficent savior and members of the community, who are often poor and minority, as victims to be saved. On this model, acts of compassionate service reify social hierarchies and maintain a cultural paradigm in which community members are perceived as suffering "other." As Mitchell puts it, "service-learning is not always the transformative pedagogy we imagine it to be" (2010, p. 94).

This article draws on a growing body of servicelearning literature that advocates for a critical service-learning pedagogy with explicit social justice aims (Adams, Bell, \& Griffin, 1997; CochranSmith, 2004; Lewis, 2004; Marullo \& Edwards, 2000; Mitchell, 2007, Mitchell \& Humphries 2007; Moely, Furco, \& Reed, 2008; Roschelle, 2000; Seider, Gillmor, \& Rabinowicz, 2010; Tinkler, Tinkler, \& Miller, 2014; Wade, 2000). Mitchell (2008) identified the "unspoken debate" between critical and traditional service-learning models, suggesting that the traditional approach "emphasizes service without attention to systems of inequality" while the critical approach "is unapologetic in its aim to dismantle structures of injustice" (p. 50). In my own classes our working definition of a socially just society is one in which there is equal opportunity for all people, regardless of socioeconomic status, race, gender, sexual orientation, nationality or immigration status, ability, religion, or other factors. Justice includes fairness in the distribution of social, economic, education, legal, and health advantages. Although educators might assume that promoting social justice is an inherent goal of service-learning, Westheimer and Kahne (2007) caution that "the link between service-learning and social justice is not guaranteed. Indeed, service-learning too often emphasizes charity at the expense of change" (pp. 99-100).

Much of the social justice-oriented literature focuses on shifting attention from the symptoms of inequality to the underlying origins and causes of oppression. For example, in her 2010 monograph,
Service-Learning and Social Justice: Engaging Students in Social Change, Cipolle identifies the goal of developing citizens who will "work to eradicate the root causes of inequity and injustice" (p. ix). This focus on the causes of injustice can be addressed through the nature of service performed, e.g. developing a political action campaign around food policy rather than volunteering in a soup kitchen. However, social justice pedagogy can also be characterized by a mode of inquiry accompanying a broad range of service. In this model, educators ask students engaged in service to simultaneously interrogate the structures of power and privilege that create, support, and perpetuate poverty, racism, and other forms of oppression.

\section{Jesuit and Mercy Education}

UDM's identity as a Jesuit and Mercy institution places it in a double-lineage of justice-oriented pedagogy, integrating the Mercy commitment to serving the poor, particularly women and children, with the Jesuit goal of forming "men and women for others." This "paramount objective" of Jesuit education was first articulated in 1973 by Rev. Pedro Arrupe, S.J., the $28^{\text {th }}$ Superior General of the Society of Jesus. Speaking to alumni of Jesuit institutions, Arrupe (1999) called on all Jesuit educators to rethink their purpose and pedagogy - to "educate for justice." Justice in the Jesuit tradition has focused on social class inequities and, since the Civil Rights Movement, has also foregrounded systemic racial inequality. The mission of the Sisters of Mercy has also evolved to include social justice advocacy around five "critical concerns," including dismantling institutional racism. Unsurprisingly, there is a particularly strong tradition of scholarship on service-learning in both Mercy and Jesuit higher education. (In the Mercy context, see Clough \& Sanders, 2008; Corrigan \& Kwasky, 2014; Groh, Stallwood, \& Daniels, 2001; Gabrich, 2007; Hermann, 2007; Weigert, 2008. In Jesuit higher education, see Cuban \& Anderson, 2007; Klos, Eskine, \& Pashkevich 2015; Lynch, Meyer, Mixak, Adamczak, \& Scott, 2012; Roschelle, Turpin, \& Elias, 2000; Seider, Gillmor, \& Rabinowicz, 2010).

Justice in the Jesuit and Mercy traditions is hands-on and experiential, essential features of service-learning. In the early years of the order, the Sisters of Mercy were known as the "walking nuns" because of their commitment to caring for the poor where they lived rather than in the confines of the cloister. Twenty-five years after the Society of Jesus formalized its commitment to "the service of faith and the promotion of justice" at the $32^{\text {nd }}$ General Congregation (1975), the $29^{\text {th }}$ Superior General, 
Rev. Peter-Hans Kolvenbach, S.J. (2000), expanded on his predecessor's vision for Jesuit education:

[T] e educate the whole person of solidarity in the real world, students, in the course of their formation, must let the gritty reality of this world into their lives, so they can learn to feel it, think about it critically, respond to its suffering, and engage in it constructively. They should learn to perceive, think, judge, choose, and act for the rights of others, especially the disadvantaged and the oppressed. ${ }^{6}$

The antithesis of the ivory tower, education "in the real world" requires that students leave the insular environment of the college campus and learn to feel, think, respond, and engage with their surroundings. In other words, students at UDM must not merely attend a university in Detroit but rather live and learn in deep engagement with the city and its diverse population.

As one of only two universities located in the city of Detroit, the university has a longstanding commitment to promoting justice in its local urban environment, an aspect of our institutional mission evident in a broad range of programs serving members of the community: summer camps for local middle and high school students; the Detroit Collaborative Design Center; the Master of Community Development program; the Center for Social Entrepreneurship; and, as of 2013, 21 universitysponsored clinics that provide free or low-cost services to members of the local community, including the Immigration Law Clinic, Juvenile Law Appellate Clinic, McAuley Health Clinic, Pediatric Dental Clinic, and Counseling Clinic. In the last several years, the university has made the community immediately surrounding the McNichols campus a top institutional priority, formalized in 2015 with the creation of the Live6 Alliance, a publicprivate partnership that aims to revitalize the neighborhoods running between UDM and Marygrove College. The name of the alliance signals its deep rootedness in the local; it is named for the intersection where the UDM McNichols campus has been located since 1927.

Undergraduates at UDM perform communityengaged service through a wide range of on- and off-campus programs, including First-Year Orientation, the Emerging Leaders Program, the University Honors Program, GM Student Corps, Alternative Breaks, Ford Community Corps Partnerships, Alpha Phi Omega (a national coeducational service fraternity), and Campus Kitchen. According to data from UDM's Institute for Leadership and Service, service-learning is incorporated into all UDM colleges and most departments, and $78.3 \%$ of UDM undergraduates take at least one service-learning class during their time at the university. Since 1995, service-learning classes at UDM have enrolled close to 20,000 students. In a school with 2,672 enrolled undergraduates (2016 data), this represents a significant feature of our educational mission.

\section{Place-Based Education}

Social justice models of service-learning are undermined if we do not incorporate critical attention to the particular local environments in which service occurs. Since the 1990s, advocates of placebased education have emphasized students' engagement with and enactive participation in their local communities (Ball \& Lai, 2006; Gruenewald, 2003; Gruenewald, \& Smith, 2014; McInerny, Smyth, \& Down, 2011; Siemers, Harrison, Clayton, \& Stanley, 2015). As with service-learning, place-based learning is experiential and hands-on, with a particular focus on developing students' understanding of and relationship with their local environment - its history, culture, politics, ecology.

In "Engaging Place as Partner," Siemers et al. (2015) lamented that too often service-learning approaches are "remarkably 'a-place' or placeneutral, uninformed by the particulars of the place and the people" (p. 101). They advocate instead for a "place-rich" or "place-engaged" approach, which promises "deeper and more critical engagement with the complexities, identities, and values of local lived experience as well as the broader historical-political-ecological-cultural forces shaping the local and intertwining it with global contexts" (p. 101). A place-engaged approach to service-learning should emerge from the particular needs of the local community, evolve in response to those needs and in collaboration with community partners, and help participating students learn "not just about, but through place" (p. 102). In other words, although a literacy program focused on expanding access to books could easily be adapted to other towns or cities, students involved in Rx for Reading Detroit should approach that work within a rich framework for understanding the interwoven dimensions of race, class, and opportunity in the city and surrounding region.

\section{The Neighborhood Effect}

A relatively new field of research offers a promising addition to place-based service-learning. Researchers in economics, education, sociology, medicine, and public policy have begun to investigate the ways in which neighborhoods - the physical, geographical, and cultural spaces in which we live 
- function as one of the most powerful determinants of residents' quality of life. (Significant overviews of this research are included in Newburger, Birch, \& Wachter 2011; Sampson, 2012; Sampson, Morenoff, \& Gannon-Rowley, 2002; Sharkey, 2013). ${ }^{7}$ Researchers have demonstrated that "ZNA," or zip code at birth, affects physical and mental health, financial security, educational attainment, exposure to crime, and access to healthcare, housing, transportation, and clean air and water. Even "microneighborhoods" as small as an individual city block can have an impact on children's future success (Tach, Jacoby, Wiebe, Guerra, \& Richmond, 2016).

Perhaps the most dramatic evidence of the socalled "neighborhood effect" is the relationship between zip code and life expectancy (Center on Society and Health, 2016; Chetty, Hendren, \& Katz, 2016). For example, the average life span in wealthy Grosse Pointe is 81 years, 11 years longer than the life expectancy in the Detroit neighborhood immediately to the west (Center on Society and Health). Both the infant morality and child/ teen death rates in Detroit are double the state average (Michigan League for Public Policy, 2016). Profound disparities like these have led to the "new mantra" in public health: "Your ZIP code matters more than your genetic code" (Hamblin, 2016).

The neighborhood in which a child lives also has a long-term impact on earning power and intergenerational economic mobility (Chetty et al., 2016). Chetty and Hendren (2015), for example, found that every year a child lives in a higherincome neighborhood increases their lifetime earnings. Rothwell and Massey (2015) determined that a child's neighborhood income had an even larger impact on their lifetime earnings than attaining a college degree. The impact of the neighborhood effect on low-income children has been exacerbated by rapidly increasing income segregation, leading to even more stark disparities in the environments in which American children grow up (Bischoff \& Reardon, 2014; Fry \& Taylor, 2012). Income segregation is a key reason why social mobility has become increasingly unattainable for children born into low socioeconomic status families (Bradbury, Corak, Waldfogel, \& Washbrook, 2015). In Detroit, children born into the bottom fifth of family income have only a 5\% chance of ending up in the top fifth (Chetty et al., 2016).

Although inequality has become more entrenched in American society, education remains the most powerful route through which children can attain higher levels of security, health, safety, and well-being than their parents. And yet access to high-quality education - and to the broad range of resources and structural conditions needed to support it - is governed by the neighborhood in which families live, work, and go to school (Crowder \& South 2010; Sampson, Sharkey, \& Raudenbush, 2008; Sharkey \& Elwert, 2011; Wodtke, Harding, \& Elwert, 2011). As wealthy and poor children are increasingly segregated by neighborhood, academic disparities have become even more intractable at every educational level. Children in lowincome neighborhoods are less likely to enroll in high-quality preschool, less likely to have access to enrichment activities, and less likely to attend well-resourced elementary and secondary schools. Unsurprisingly, low-income teens are less likely to graduate high school, less likely to attend college and, once there, less likely to graduate. Even as educational disparities between Black and White children have narrowed, the gap between rich and poor children has increased by as much as $30-40 \%$ over the last 25 years (Reardon, 2011).

As in much of the country, the so-called "achievement gap" between wealthy and poor children in Michigan emerges early and persists at every educational level (Bailey \& Dynarski, 2011a; Bailey \& Dynarski, 2011b; Dahl \& Lochner, 2012; Duncan \& Murnane, 2011; Reardon, 2011, 2013; Schubert $\&$ Becker, 2010). Reading proficiently by the end of third grade is the single most significant predictor of high school graduation and a successful career (Annie E. Casey Foundation, 2013). Students who are not reading proficiently by this time are more than four times more likely to drop out of high school, and educational attainment is strongly correlated with lifetime earnings (Hernandez, 2011). In Michigan, only $16 \%$ of low-income children are reading proficiently by the end of $3^{\text {rd }}$ grade, compared to $40 \%$ of more affluent children (Annie E. Casie Foundation, 2015). ${ }^{8}$ In Detroit, where $85 \%$ of children live in high poverty areas (Annie E. Casey Foundation, 2015), only 6\% of public school students are reaching the critical benchmark (National Center for Education Statistics, 2015). Detroit now ranks as the lowest performing large urban district in the country as measured by the National Assessment of Educational Progress (NAEP) exam.

In September 2016, the class action suit Gary B. v. Snyder (2016) was filed on behalf of seven Detroit students at some of the lowest-performing public and charter schools in the district. This is the first federal case to argue that all students have the constitutional right to literacy, the "most basic building block of education" (p. 4) which is "necessary to participate in college and career, and as citizens in our democracy" (p. 17). The complaint argues that "by its actions and inactions, the State of Michigan's systemic, persistent, and deliberate 
failure to deliver instruction and tools essential for access to literacy in Plaintiffs' schools, which serve almost exclusively low-income children of color, deprives students of even a fighting chance" ( $p$. $4)$. In their motion to dismiss the case, filed in November 2016, the State of Michigan has argued that there is no constitutional right to literacy.

The ecological reality of the neighborhood effect belies the core ideal of the American dream - the belief that, wherever we come from and whoever our parents are, we can succeed with hard work and determination. Helping university students recognize the local factors that contribute to inequality is indispensible for moving them toward a social justice paradigm because most students agree with the basic principle that the place of a child's birth should not determine her health, safety, or access to a quality education. Framing social justice in terms of localized structures of inequality, as opposed to the suffering of individuals, helps circumvent a number of interpretive failures that are an inherent risk to service-learning: attributing social problems to flaws or weaknesses in individuals or groups; attaching poverty to racial stereotypes or other implicit biases; and internalizing a deficit view of lowincome families and communities. Instead, students need to reflect on the ways that environment itself expands and constrains opportunity. This gives us common ground on which to build social justice theory and practice.

\section{Book Deserts in Detroit: Literacy as Social Justice}

Needless to say there are multifaceted and intersecting features to the opportunity gap between American neighborhoods. I have already suggested that disparities in public school funding and community resources are one essential factor. Another underlying cause, however, is disparate access to age-appropriate reading material. A large body of research has demonstrated that access to books is a critical factor in early childhood literacy (Lindsay, 2010; Neuman \& Celano, 2001; Scholastic, 2013). Access to books has immediate and long-term effects on children's vocabulary, comprehension, and school readiness (Allington et al, 2010; Neuman, 1999), improving both reading performance and children's attitudes toward reading (Lindsay, 2010). In fact, the number of books in a child's home is one of the most important predictors of her educational attainment (Evans, Kelley, Sikora, \& Treiman, 2010) and lifetime earnings (Brunello, Weber, \& Weiss 2016; Mullis, Martin, Foy, \& Drucker, 2012).

While affluent neighborhoods are print rich
(Neuman \& Celano, 2001), much of Detroit is classified as a "book desert," a community or neighborhood with severely constrained access to ageappropriate reading material. This result is most pronounced in high-poverty neighborhoods. In Hamtramck, which has a $67 \%$ childhood poverty rate, researchers found one children's book available for every 42 children (age 0 to 18 ) and only one age-appropriate book for every 37 children age five and under (Neuman \& Moland, 2016). Even in University District, the neighborhood to the north of UDM's McNichols campus which has a comparatively low $32 \%$ childhood poverty rate, the researchers found only one book available for every 11 children. In addition to limited stores in which families can purchase books, libraries throughout Detroit have been shuttered, and many families do not have reliable transportation to the ones that remain. ${ }^{9}$ Fines are also a deterrent to library usage. $22 \%$ of Detroit Public Library patrons carry longterm debt on their records, and $14 \%$ of customers $(56,191$ individuals) have unpaid fines of $\$ 10$ or more, meaning they cannot borrow materials or use public access computers (2017 institutional data). Many classroom and school libraries are also woefully inadequate, an issue highlighted in Gary B. v. Snyder. One of our first Head Start partners had 15 books, one for each child; they were not in the classroom but locked away in the office so they would last another year.

Expanding access to print material is certainly not a panacea for educational disparities; books are necessary for educational equality but not sufficient. Indeed, some critics would categorize the redistribution of resources like books as an act of charity rather than justice. However, the distribution of books is not simply a charitable "bandaid" that remedies a symptom of injustice; Rx for Reading Detroit attacks a root cause of economic and educational inequality in our region. This is not to say that the intractability of poverty can be solved by flooding a neighborhood with books. After all, book deserts are a symptom of economic oppression as much as a contributing cause. But we also cannot dismiss the causal relationship between access to resources and economic and racial justice, a correlation that is particularly acute for resources that are necessary for educational equity and its long-term impacts for individuals, families, and communities.

Confronting the long-term implications of unequally resourced neighborhoods helps students recognize that injustice must be dismantled through environmental, rather than personal, solutions. The metaphor of a book desert is useful here because of its rootedness in place. Illiteracy, the metaphor 
suggests, is caused not by parents, teachers, or children but by an environment that does not support reading. Ironically, although a place-based approach encourages students to recognize the structural obstacles to equality, it does not necessarily make those obstacles feel intractable. Once we drill down to the micro-environments in which books and other resources can be acquired, students begin to recognize the significant impact environmental interventions can have. For example, Neuman and Moland (2016) found a total of 876 children's books for sale in University District, the 323-acre neighborhood contiguous to UDM's campus. Since they conducted their count, children and families in the neighborhood have selected over 3,500 children's books from Rx for Reading Detroit community libraries, effectively transforming the landscape of print culture in that neighborhood. Complicating a simple dichotomy between charity and social justice, Marullo and Edwards (2000) offer a useful paradigm for how the redistribution of resources like books can "become political":

(a) as a part of a larger political change strategy or process, in which charitable acts can lead to a redistribution of resources that changes institutions, and (b) as a first step in a process of politicization that puts community service volunteers on the path to becoming active agents of social change. (p. 900)

This paradigm maps nicely onto the two social justice goals of Rx for Reading Detroit: expanding opportunity for low-income children in Detroit and mobilizing college students as politicized voters and activists.

As part of our place-based approach to service, Rx for Reading Detroit asks participating students to identify community spaces in which families find support, care, and community. We started our work by creating waiting room libraries in lowincome health and dental clinics so that healthcare providers who talk with families about the importance of reading can also invite children to choose new books to take home. Gradually we expanded to WIC clinics, homeless shelters, community centers, and churches. These are not places dedicated to reading; rather, books can permeate spaces in which families already visit. As the ultimate portable object, books move from community spaces into the home environments of children, where they have been shown to have such a powerful impact on literacy and academic success.

As our program has grown we have created a map of sorts across the city of Detroit, one that that links organizations committed to children and families and willing to "make space" for reading. De- troit Mercy students learn to navigate this terrain, delivering books, setting up libraries, and reading with children in Head Start and elementary classrooms, one of the most essential environments in which readers can flourish. Working in partnership with community organizations allows us to respond to self-identified community needs while we remain attuned to "ecological differences" between neighborhoods. In Southwest Detroit, for example, we include Spanish and bilingual books in all of our libraries. Similarly, the "take a book, leave a book" philosophy of the Little Free Library movement is ill-suited for an under-resourced community. Rx for Reading libraries carry the message "Take, Read, Share." This culturally-aware, geographicallyspecific model of distribution is inseparable from our broader goal of creating an urban environment saturated with print.

I have argued that students who participate in Rx for Reading Detroit promote social justice goals by tackling an underlying cause of inequality - inadequate access to print material. Social-justice pedagogy has additional demands: It requires engaging students in a mode of inquiry about the systemic causes of inequality that extends beyond the immediate service they perform. Students who work to expand access to books in Detroit must understand their work in the context of what Stephen Henderson (2016) calls the "calcified inequality" in Michigan's educational system, as well as mutually reinforcing disparities in housing, healthcare, security, and transportation. As just one example of the imbrication between social institutions, youth with low literacy skills are disproportionately more likely to end up in the juvenile and criminal justice systems, undermining family and community stability in high-poverty neighborhoods and increasing the chances that children and families will remain poor. As this example suggests, a social justice approach should challenge students to recognize the intricate overlappings of social and economic oppression in their local environment.

\section{"Education in an Urban Context"10: Place, Perspective, and Power}

UDM is physically located in three distinct neighborhoods in the city: the School of Law is in downtown Detroit, the School of Dentistry is in Corktown, and the McNichols Campus is in northwest Detroit. On the McNichols campus, located at 6 Mile and Livernois, undergraduates from across the region come together in a shared urban and architectural space. The radical nature of the college classroom as contact zone can only be fully appreciated when it is compared to ele- 
mentary and secondary education in Michigan, where income segregation and school zoning have severely contracted geographic, racial, and class diversity. Although all students at UDM are educated "in the D," they experience radically different relationships with the city and its people depending on their own geographic, economic, and cultural "place." Some of my students are lifelong Detroit residents; others have never set foot in the city before visiting campus. Of the $9.4 \%$ of our students from the city, $83.9 \%$ are Black or Latino; of the $66.9 \%$ of students from Metro Detroit suburbs, 66\% are white (2015 institutional data). Undergraduates from wealthy suburbs, even ones whose resumes are filled with volunteerism, are often unaware of just how uneven the playing field is in the distribution of social, economic, education, legal, and health advantages.

A more robust and critical analysis of the intersections between place and race in America is essential if we are to recognize and value the diverse perspectives students bring to service and avoid the pitfalls of service-learning as a "pedagogy of whiteness" (Mitchell, Donahue, \& Young-Law, 2012, p. 612). Rather than erase or conflate students' perspectives, we can bring them to bear in servicelearning in ways that help students recognize their own complex relationships with their community and the people they serve. Too often these differences remain implicit or under-theorized in the service-learning literature and ignored in servicelearning classrooms. Place-based social justice pedagogy can be transformative for those students who encounter Detroit as an outsider or newcomer. It is equally important, however, for students for whom service in Detroit is not a "border crossing" but a "returning home" to their community (Mitchell et al., p. 620).

Notwithstanding University of Detroit Mercy's deep commitment to its urban context, the relationship between "town and gown" is not uncomplicated. There is inherent friction to being an institution of higher learning in a city stymied by unequal and inadequate access to educational resources. This tension is magnified because Detroit Mercy is a predominantly White institution in a predominantly Black neighborhood and city. As with all nonprofit universities, UDM does not contribute to the local tax base of Detroit. Although employees pay city taxes on their income, the majority of UDM's faculty and staff do not live in the city or pay property taxes; very few of their children attend Detroit public schools. The relationship between the McNichols campus and its immediate neighborhood is also ambivalent, despite the recent attention to building bridges. Some of our neighbors come to campus regularly to use the library, attend sporting events, or bring their children to Safety Street - a free Halloween event in its $26^{\text {th }}$ year. However, there are still lingering tensions from the installation of an 8foot tall security fence around the perimeter of the campus, and several years ago the administration instituted an ID policy that would make it easier for the UDM Department of Public Safety to identify individuals who are not employees or students. Many individuals on campus have resisted the policy because of the concern that it creates a mentality of "us versus them."

Place-based social justice pedagogy is critical because of, not in spite of, these complexities. In fact, they offer unique opportunities for learning and analysis. For example, a colleague in the English department has first-year composition students write a "con(textual) analysis" of the security fence itself, examining how the 8-foot tall, wrought iron barrier functions as a text that communicates different messages to different audiences depending on their perspective. First students write from a vantage point on campus: What does the fence communicate to students, faculty, staff, and even parents? Then they are asked to sit across the street to consider what it communicates to individuals who are in the neighborhood but outside of the fence. Students themselves might inhabit both perspectives depending on their own neighborhood of origin and their relationship with the surrounding community.

A place-based pedagogy facilitates this kind of meta-analysis by foregrounding the ways that place and race define one's perspective. One way service-learning educators can help move students into an analytic framework is by recognizing, calling attention to, and interrogating how language reflects and potentially inflects our "ways of seeing." For example, how does our understanding of what happened in Detroit in 1967 change depending on whether we use the phrase "race riots" or "the uprising," whether we call it an insurrection or rebellion? For that matter, how does our understanding change depending on the "place" of the person who gets to tell the story? The events are understood and communicated differently by a White resident who subsequently moved out of the city or by another colleague of mine, Ike McKinnon, who was serving as one of the first African-American officers in the Detroit Police Department.

As this example suggests, language is not politically neutral; it is an expression of power and privilege that can authorize or delegitimize the voices of individuals and groups. The language of servicelearning, Mitchell et al. (2012) caution, can also 
have unintended and deleterious effects: "the words 'underprivileged' and 'at risk,' for example, can reinforce stereotypes based in white supremacy" (p. 614). Language can also reveal power struggles, as is evident in the "rebranding" of Cass Corridor and other neighborhoods in the city (DeVito, 2015; Jackman, 2014). ${ }^{11}$ Who gets to name a neighborhood - its long-time residents or powerful real estate developers? Who gets "control" over a neighborhood's identity and story, not to mention its resources? These questions are critical because students engaged in service inevitably create a narrative about the communities in which they serve. I encourage students to become attuned to how language affects our own place-based perspectives and make conscious choices about how they talk about Detroit and its citizens, including whether or not they call themselves or see themselves as Detroiters.

Although language can act as a mode of oppression, it can also make positive claims on social and ethical relationships, a feature of which Putnam was certainly cognizant when he titled his recent book, Our Kids: The American Dream in Crisis (2015). Condemning the growing opportunity gap between rich and poor children, Putnam's primary audience is one of highlyeducated, economically-secure readers. And yet his use of the word "our" to describe children living in poverty eschews an "us and them" dynamic that would serve to divide rather than unite. Moreover, it makes ethical claims on all of us; it is our shared national responsibility to protect and educate all of "our" children.

Similarly, when I write about Rx for Reading Detroit for an audience of donors or community partners I consistently communicate the message that Detroit is "our community." I use the pronoun "our" to call on relationships of mutual obligation, reciprocity, and kinship. These dynamics are also implicit to the tagline of Rx for Reading Detroit - "Raising Readers, One Book at a Time." We are all responsible for raising (elevating, empowering) children in Detroit. These rhetorical effects are implicit for a public audience, but when I talk with students we can analyze the intention of language as well as its impact, including the more ambivalent effects. After all, the pronoun "our" effaces the reality that UDM students and supporters of Rx for Reading Detroit have very different relationships with the city depending on their race, class, and zip code. Insofar as we are "raising readers," we also need to be clear that we are supporting, not supplanting, the role of families in raising (nurturing, rearing, bringing up) their children.

\section{Place-Based Pedagogy \\ in the Literature Classroom}

Rx for Reading Detroit offers a unique model of service-learning because, as a professor, I also serve as the director of the organization with which students serve. As such I have the opportunity to incorporate learning and reflection both in and outside of the service-learning classroom. I might drop in while students are sorting books for delivery or touch base as they prepare to read with one of our Head Start partners. These informal interactions give me the opportunity to talk with students about the rationale for the program, their own relationship to reading and books, and what it means to work in, for, and with Detroit. For example, I often talk with students about the importance of including children's books with characters from culturally diverse backgrounds, particularly in a city that has a majority-minority population.

In service-learning classes, I am able to address these issues in a more sustained fashion that makes explicit connections with students' disciplinary learning. For example, in a service-learning course on Diverse Voices in Literature we start the semester by reading Toni Morrison's first novel, The Bluest Eye, which takes place in 1940's Lorain, Ohio. The novel is a helpful entrée to examining the relationship between geography and opportunity. Although The Bluest Eye is about fictional characters, Morrison's portrait of the town she grew up in reveals the historical and geographical obstacles to social justice in $20^{\text {th }}$ century American society, particularly for young Black girls. Morrison highlights the critical role of environment with the opening metaphor of the novel, which imagines marigold seeds that cannot grow in the "plot of black earth" (p. 6) in which they are planted. The fate of Pecola Breedlove and her stillborn child, the novel suggests, is a function of an environment that cannot bear fruit.

Through classroom discussion students are able to identify the environmental obstacles to Pecola's and other characters' "flourishing": entrenched racism and misogyny; segregation; inadequate access to education, healthcare, and employment; and a culture that conspires to value Whiteness at the expense of Black lives and bodies. Racial and class inequality materializes through geography midway through the novel, as Pecola's friends walk from their neighborhood to the one in which her mother works for a White family. There the houses are newer and even the skies seem, or perhaps are, more blue. The girls are fully cognizant of the ways in which they are excluded from social spaces and the opportunities they embody. "Black people were not allowed in the park," the narrator recalls, "and so it filled our dreams" (p. 105). 
One risk of reading "historical" literature is that students analyze structures of inequality but dismiss them as something from the distant past. I have found it useful to accompany Morrison's novel with McIntosh's essay, "White Privilege: Unpacking the Invisible Knapsack." Students respond to the essay by writing a list of their own conditions of privilege as well as the "interlocking" systems of dominance and oppression they have experienced. These lists are vastly different in a university with a diverse student body. In conversation after this exercise one student observed that she grew up with hundreds of children's books, most of which had characters that looked like her. Another responded that she had only one book at home, a Little Red Riding Hood coloring book. The goal is not necessarily for students to compare their experiences with each other in this way, but rather to critically examine their personal relationship with structural privilege, including their own access to higher education. Sequenced written assignments extend their analysis, as students develop their own working definition of social justice, write a literary analysis that examines the seemingly insurmountable barriers to justice in Morrison's novel, and write a "debriefing" reflection that considers whether or not the barriers to equal opportunity that Morrison identifies in 1940s Ohio still exist in American society. Although this is a class on literature rather than public policy, I ask students to consider what political, economic, or social interventions they think are needed to combat inequality in our region, thus pushing them to consider key areas of social justice action beyond their immediate work for Rx for Reading Detroit.

As my use of The Bluest Eye suggests, educators who adapt a place-based social justice pedagogy can capitalize on its particular connections to the texts, theories, and methods of their discipline. In my own field of literary studies, for example, the analysis of character, setting, and perspective can help students recognize that our point of view what and how we see as well as the attitudes and beliefs that shape our perception - is inevitably constrained by our location in geographic space, in family, in society. In this way literary analysis can serve as a methodological tool to help students frame their experience of service in Detroit. Do we approach the city as native or observer, participant or witness, resident or citizen? What effect does where they come from have on how they perceive the city in which they serve and go to school?

Just as literary analysis can enhance servicelearning, interrogating students' experience of service also informs our reading of literature. For example, many students who read fiction experience profound feelings of connection to the characters they encounter. Studies on narrative empathy bear this out, demonstrating that literary texts regularly guide readers in perspective-taking and shared affect with fictional characters, even when those characters are from social groups or backgrounds different from their own (Harrison, 2011; Keen, 2007; Kidd \& Castona, 2013; Mar \& Oatley, 2008; Moya, 2015). Narrative empathy can have ethically salutary effects when it helps readers connect with characters from diverse backgrounds and identities, particularly when it invites a relational stance of solidarity rather than generosity, "feeling with" rather than "feeling for" (Harrison, 2008; Vezalli, Stathi, Giovannini, Capozza, \& Trifileti, 2015). However, place-based social justice pedagogy also helps students recognize the limits of empathy the ways in which perspective is bounded by our own experience and identity (Harrison, 2011). This caveat is necessary if students are to avoid an uncritical assumption that they can understand what another person feels and knows, regardless of their own "place" in the world.

\section{Notes}

1 To qualify for the NSLP (National School Lunch Program) children must come from families whose income is $185 \%$ of the federal poverty level or below. $46.7 \%$ of children in the state qualify for the program.

${ }^{2}$ The map was created from 2010 U.S. Census data while Cable was a demographer at University of Virginia's Weldon Cooper Center for Public Service. Census data is based on individuals' selfreported racial and ethnic identity.

${ }^{3}$ High poverty areas are defined as census tracts with poverty rates of $30 \%$ or higher.

${ }^{4}$ We extend our work to Highland Park and Hamtramck, two municipalities surrounded by the city of Detroit.

${ }^{5} \mathrm{Rx}$ for Reading Detroit is not associated with the incorporated non-profit Little Free Library®, through which consumers can purchase libraries and other branded items or pay a $\$ 40$ fee to "register" a library they have installed. As Schmidt \& Hale (2017) have noted, the majority of LFLs ${ }^{\circledR}$ are located in affluent, predominantly white neighborhoods and, as such, do not function to decrease social inequality. Moreover, by contributing to the corporatization and "neoliberalization" (32) of social services LFLs ${ }^{\circledR}$ can undermine public funding for much-needed resources in marginalized and under-served communities, including public libraries. Our model of community-based collaboration is designed to support rather than supplant pub- 
licly-funded organizations working on behalf of low-income children and families.

6 These comments were made at the first national conference on "Commitment to Justice in Jesuit Higher Education" that included representatives from all 28 Jesuit colleges and universities in America. The fourth national Justice Conference will be held in 2017 .

7 This field emerged from William Julius Wilson's seminal 1987 text, The Truly Disadvantaged: The Inner City, the Underclass, and Public Policy.

${ }^{8}$ This data compares the reading scores on the $4^{\text {th }}$ grade National Assessment of Educational Progress (NAEP) exam for children who qualify for free and reduced lunches and those who do not.

${ }^{9}$ Nineteen percent of Detroit children live in families without access to a vehicle, compared to $5 \%$ of children in Michigan (Annie E. Casey Foundation, 2015). In an analysis of community use of public transportation, Detroit's regional transportation system was ranked last in a comparison of 15 U.S. urban areas with a population over $3,000,000$ (Fisher-Baum, 2014).

${ }^{10}$ From UDM's mission statement.

${ }^{11}$ In University District there is a movement to rebrand the "Avenue of Fashion" as "Gallery Row." As with Cass Corridor and Midtown, what name someone uses is a pretty good indicator of how long they have been in the neighborhood.

\section{References}

Adams, M., Bell, L. A., \& Griffin, P. (Eds.) (1997). Teaching for diversity and social justice: A sourcebook. New York: Routledge.

Allington, R., McGill-Franzen, A., Camilli, G., Williams, L., Graff, J., Zeig, J., \& Nowak, R. (2010). Addressing summer setback among economically disadvantaged elementary students. Reading Psychology, 31(5), 411427.

Annie E. Casey Foundation (2010). Early warning! Why reading by the end of third grade matters. Baltimore, MD: Annie E. Casey Foundation.

Annie E. Casey Foundation (2013). Early warning confirmed: A research update on third grade reading. Baltimore, MD: Annie E. Casey Foundation.

Annie E. Casey Foundation (2015). Kids count data center. Retrieved from http://datacenter.kidscount.org

Arrupe, P. (1999). Men and women for others. In J. Callahan (Ed.), First principles: The Jesuit tradition in higher education. Kansas City, MO: JJ Callahan.

Bailey, M. J., \& Dynarski, S. M. (2011a). Gains and gaps: Changing inequality in U.S. college entry and completion (No. w17633). Cambridge, MA: National Bureau of Economic Research.

Bailey, M.J. \& Dynarski, S.M. (2011b). Inequality in postsecondary education. In G.J. Duncan \& R.J. Mur- nane (Eds.), Whither opportunity? Rising inequality, schools, and children's life chances (pp. 117-132). New York: Russell Sage Foundation \& Spencer Foundation.

Ball, E. L., \& Lai, A. (2006). Place-based pedagogy for the arts and humanities. Pedagogy, 6(2), 261-287.

Bischoff, K., \& Reardon, S. F. (2014). Residential segregation by income, 1970-2009. In J. Logan (Ed.), Diversity and disparities: America enters a new century. New York: The Russell Sage Foundation.

Bradbury, B., Corak, M., Waldfogel, J., \& Washbrook, E. (2015). Too many children left behind: The U.S. achievement gap in comparative perspective. New York: Russell Sage Foundation.

Brunello, G., Weber, G., \& Weiss, C. T. (2016). Books are forever: Early life conditions, education and lifetime earnings in Europe. The Economic Journal. doi: 10.1111/ecoj.12307

Center on Society and Health (2016). Mapping Life Expectancy: Detroit. Richmond, VA: Virginia Commonwealth University. Retrieved from http://www.societyhealth.vcu.edu/work/the-projects/mapsdetroit.html

Chetty, R. \& Hendren, N. (2015). The impacts of neighborhoods on intergenerational mobility: Childhood exposure effects and county-level estimates (Working Paper 23001). Cambridge, MA: National Bureau of Economic Research.

Chetty. R, Hendren N., \& Katz L.F. (2016). The effects of exposure to better neighborhoods on children: New evidence from the moving to opportunity experiment. The American Economic Review, 106(4), 855-902.

Chetty, R., Stepner, M., Abraham, S., Lin, S., Scuderi, B., Turner, N. et al. (2016). The association between income and life expectancy in the United States, 20012014. Journal of the American Medical Association, 315(16), 1750-1766.

Cipolle, S. B. (2010). Service learning and social justice: Engaging students in social change. Lanham, MD: Rowman \& Littlefield.

Clough, J., R.S.M., \& Sanders, S. R.S.M. (2008). Service learning in a Catholic and Mercy context. The MAST Journal, 18(2), 20-26.

Cochran-Smith, M. (2004). Walking the road: Race, diversity, and social justice in teacher education. New York: Teachers College Press.

Cooper, D. (2013). Racial dot map. Charlottesville, VA: Weldon Cooper Center for Public Service. Retrieved from http://www.coopercenter.org/demographics/Racial-Dot-Map

Corrigan, C. P., \& Kwasky, A. N. (2014). Utilizing service-learning to promote a value based professional nursing curriculum. Creative Education, 5(21), 1848.

Crowder, K. \& South, S. J. (2011). Spatial and temporal dimensions of neighborhood effects on high school graduation. Social Science Research, 40(1), 87-106.

Cuban, S., \& Anderson, J. B. (2007). Where's the justice in service-learning? Institutionalizing service-learning from a social justice perspective at a Jesuit university. Equity \& Excellence in Education, 40(2), 144-155. 
Dahl, G.B. \& Lochner, L. (2012). The impact of family income on child achievement: Evidence from the earned income tax credit. American Economic Review, 102(5), 1927-1956.

DeVito, L. (2015, January 07). Welcome to 'Springwells Village' - a southwest Detroit neighborhood most of its own residents have never heard of. Retrieved from http://m.metrotimes.com/detroit/welcome-to-springwells-village-a-southwest-detroit-neighborhoodmost-of-its-own-residents-have-never-heard-of/Content?oid $=2277537 \&$ storyPage $=1$

Duncan G.J., \& Murnane, R.J. (Eds.) (2011). Whither opportunity? Rising inequality, schools, and children's life chances. New York: The Russell Sage Foundation $\&$ Spencer Foundation.

Economic Innovation Group (2016). The 2016 Distressed Communities Index. Washington, DC: Economic Innovation Group.

EdBuild (Aug. 22, 2016). Fault lines: America's most segregating school district borders. Jersey City, NJ: EdBuild.

Evans, M. D., Kelley, J., Sikora, J., \& Treiman, D. J. (2010). Family scholarly culture and educational success: Books and schooling in 27 nations. Research in social stratification and mobility, 28(2), 171-197.

Fischer-Baum, Reuben (July 31, 2014). How your city's public transportation stacks up [Web log post]. Retrieved from https://fivethirtyeight.com/datalab/howyour-citys-public-transit-stacks-up/

Freire, P. (2000). Pedagogy of the oppressed. London: Bloomsbury Publishing.

Fry, R., \& Taylor, P. (2012). The rise of residential segregation by income. Washington, D.C.: Pew Research Center.

Gabrich, C. (2007). Service learning: The power of university-community connections. Carlow Roundtable 2007 Proceedings, 91-95. Pittsburgh, PA: The Carlow University Press.

Galanes, P. (2014, November 28). Elton John and Darren Walker onr, sexual identity and leaving the past behind. The New York Times. Retrieved from http://www. nytimes.com/2014/11/30/fashion/elton-john-and-darren-walker-on-race-sexual-identity-and-leaving-thepast-behind.html?_r=0

Gary B. v. Snyder, 16-CV-13292. (Michigan Eastern District Court, filed 2016).

Groh, C. J., Stallwood, L. G., \& Daniels, J. J. (2011). Service-learning in nursing education: Its impact on leadership and social justice. Nursing Education Perspectives, 32(6), 400-405.

Gruenewald, D. A. (2003). The best of both worlds: A critical pedagogy of place. Educational researcher, 32(4), 3-12.

Gruenewald, D. A., \& Smith, G. A. (Eds.). (2014). Placebased education in the global age: Local diversity. New York: Lawrence Erlbaum Associates.

Harrison, M. C. (2008). The paradox of fiction and the ethics of empathy: Reconceiving Dickens's realism. Narrative, 16(3), 256-278.
Harrison, M. C. (2011). How narrative relationships overcome empathic bias: Elizabeth Gaskell's empathy across social difference. Poetics Today, 32(2), 255288.

Henderson, S. (2016, June 4). Michigan House's Detroit school bills are pure garbage, not about kids. Detroit Free Press. Retrieved from http://www. freep.com/story/opinion/columnists/stephen-henderson/2016/06/03/dps-reform-legislation/85348006/

Hernandez, D. (2011). Double jeopardy: How thirdgrade reading skills and poverty influence high school graduation. Baltimore: The Annie E. Casey Foundation.

Herrmann, M. (2007). The Mercy mission reflected in our pedagogy and curriculum: Mercy and justice, the humanities. Carlow Roundtable 2007 Proceedings (pp. 13-16). Pittsburgh, PA: The Carlow University Press.

Jackman, M. (2014, August 26). Probing the Cass corridor-Midtown fault line in the news. Detroit Metro Times. Retrieved from http://www.metrotimes.com/ Blogs/archives/2014/08/26/probing-the-cass-corridormidtown-fault-line-in-the-news

Keen, S. (2007). Empathy and the novel. Oxford: Oxford University Press.

Kidd, D. C., \& Castano, E. (2013). Reading literary fiction improves theory of mind. Science, 342(6156), 377-380.

Klos, N. Y., Eskine, K., \& Pashkevich, M. (2015). Assessing social justice as a learning outcome in honors. Journal of the National Collegiate Honors Council, 16(1), (53-70).

Kolvenbach, P. H. (2000). The service of faith and the promotion of justice in American Jesuit higher education. In G. W. Traub (Ed.), A Jesuit education reader. Chicago: Loyola University Press.

Lewis, S.D. (Aug. 22, 2016). “Detroit, G.P. schools' economic divide listed as worst." The Detroit News. Retrieved from http://www.detroitnews.com/story/news/ local/detroit-city/2016/08/22/detroit-grosse-pointeschools-economic-divide/89131386/

Lewis, T. L. (2004). Service learning for social change? Lessons from a liberal arts college. Teaching Sociology, 32(1), 94-108

Lindsay, J. (2010). Children's access to print material and education-related outcomes: Findings from a meta-analytic review. Napervile, IL: Learning Point Associates.

Logan, J. R., \& Stults, B. (2013). The persistence of segregation in the metropolis: New findings from the 2010 census. City \& Community (12)2, 160-168.

Lynch, P., Meyer, G., Mixak, P., Adamczak, C., \& Scott, K. (2012). Values of exemplary Jesuit college graduates. Jesuit Higher Education: A Journal, 1(2), Article 15.

Maas Weigert, K. (2008). The mercy call to learn and serve for social justice. The MAST Journal, 18(2), 2-7.

Mack, J. (Nov. 2, 2015). Michigan college-going rate dips. MLive. Retrieved from http://s.mlive.com/AKVvB6S 
Mar, R. A., \& Oatley, K. (2008). The function of fiction is the abstraction and simulation of social experience. Perspectives on psychological science, 3(3), 173-192.

Marullo, S., \& Edwards, B. (2000). From charity to justice: The potential of university-community collaboration for social change. American Behavioral Scientist, 43(5), 895-912.

McInerney, P., Smyth, J., \& Down, B. (2011). Coming to a place near you?: The politics and possibilities of a critical pedagogy of place-based education. AsiaPacific Journal of Teacher Education, 39(1), 3-16.

McIntosh, P. (1988). White privilege: Unpacking the invisible knapsack. In P. S. Rothenberg (Ed.), Race, class, and gender in the United States: An integrated study. New York: Worth Publishers.

Michigan Department of Education (2016). MI School Data. Searchable database built by Detroit Free Press. Retrieved from http://www.freep.com/pages/interactives/2016-mstep-sat-michigan-results/

Michigan League for Public Policy (2016). Kids count in Michigan data book 2016. Lansing, MI: Michigan League for Public Policy.

Milliken v. Bradley. 418 U.S. 717. (Supreme Court, 1974).

Mitchell, T. D. (2007). Critical service-learning as social justice education: A case study of the citizen scholars program. Equity \& Excellence in Education, 40(2), 101- 112.

Mitchell, T. D. (2008). Traditional vs. critical servicelearning: Engaging the literature to differentiate two models. Michigan Journal of Community Service Learning, 14(2), 50-65.

Mitchell, T. D. (2010). Challenges and possibilities: Linking social justice and service-learning. [Review of the book Service-learning and social justice: Engaging students in social change]. Michigan Journal of Community Service Learning, 17(1), 94-97.

Mitchell, T. D., Donahue, D. M., \& Young-Law, C. (2012). Service learning as a pedagogy of whiteness. Equity \& Excellence in Education, 45(4), 612-629.

Mitchell, C., \& Humphries, H. (2007). From notions of charity to social justice in service-learning: The complex experience of communities. Education as Change, 11(3), 47-58.

Moely, B., Furco, A., \& Reed, J. (2008). Charity and social change: The impact of individual preferences on service-learning outcomes. Michigan Journal of Community Service Learning, 15(1), 37-48.

Morrison, T. (1994). The bluest eye. New York: Plume.

Moya, P. (2015). The social imperative: Race, close reading, and contemporary literary criticism. Stanford, CA: Stanford University Press.

Mullis, I., Martin, M., Foy, P., \& Drucker, K. (2012). PIRLS 2011 International Results in Reading. Chestnut Hill, MA: PIRLS International Study Center Boston College.

National Center for Education Statistics (2015). The Nation's report card. Washington, DC: U.S. Department of Education.
Neuman, S. (1999). Books make a difference: A study of access to literacy. Reading Research Quarterly, 34(3), 286-311.

Neuman, S., \& Moland, N. (2016) Book deserts: The consequence of income segregation on children's access to print. Urban Education, 1, 1-22.

Neuman, S., \& Celano, D. (2001). Access to print in lowincome and middle-income communities: An ecological study of four neighborhoods. Reading Research Quarterly, 36(1), 8-26.

Newburger, H., Birch, E. L., \& Wachter, S. M. (2011). Neighborhood and life chances: How place matters in modern America. Philadelphia: University of Pennsylvania Press.

Putnam, R. (2015). Our kids: The American dream in crisis. New York: Simon \& Schuster.

Reading Is Fundamental (2010). Access to print materials improves children's reading: A meta-analysis of 108 most relevant studies shows positive impacts. Retrieved from http://www.marketwired. com/press-release/new-research-shows-accessto-print-materials-improves-childrens-reading-1322432.htm

Reardon, S. F. (2011). The widening academic achievement gap between the rich and the poor: New evidence and possible explanations. In R. Murnane \& G. Duncan (Eds.) Whither opportunity? Rising inequality and the uncertain life chances of low-income children. New York: Russell Sage Foundation.

Reardon, S. F. (2013). The widening income achievement gap. Educational Leadership, 70(8), 10-16.

Reese, L., Eckert, J., Sands, G., Vojnovic, I. (2017), "It's safe to come, we've got lattes": Development disparities in Detroit. Cities, 60, 367-377.

Reese, L. \& Sands, G. (Feb. 6, 2017). Detroit's recovery: The glass is half-full at best. The Conversation. Retrieved from https://theconversation.com/detroitsrecovery-the-glass-is-half-full-at-most-69752

Roschelle, A. R., Turpin, J., \& Elias, R. (2000). Who learns from service learning? The American Behavioral Scientist, 43(5), 839-847.

Rothwell, J. T. \& Massey, D. S. (2015), Geographic effects on intergenerational income mobility. Economic Geography, 91, 83-106.

Sagan, C. (1995). Demon-haunted world: Science as a candle in the dark. New York: Random House Publishing Group.

Sampson, R. J. (2012). Great American city: Chicago and the enduring neighborhood effect. Chicago: University of Chicago Press.

Sampson, R. J., Morenoff, J. D., \& Gannon-Rowley, T. (2002). Assessing "neighborhood effects": Social processes and new directions in research. Annual review of sociology, 28, 443-478.

Sampson, R. J., Sharkey, P., \& Raudenbush, S. W. (2008). Durable effects of concentrated disadvantage on verbal ability among African-American children. Proceedings of the National Academy of Sciences, 105(3), 845-852.

Scholastic Family and Community Engagement (FACE). 
(2013). Make every student count: Family and community engagement 2013 research compendium. New York: Scholastic. Retrieved from http://teacher.scholastic.com/products/face/pdf/research-compendium/ Compendium.pdf

Schubert, F., \& Becker, R. (2010). Social inequality of reading literacy: A longitudinal analysis with crosssectional data of PIRLS 2001 and PISA 2000 utilizing the pair wise matching procedure. Research in Social Stratification and Mobility, 29, 109-133.

Schmidt, J. \& Hale, J. (2017). Little Free Libraries®: Interrogating the impact of the branded book exchange. Journal of Radical Librarianship, 3: 14-41.

Seider, S. C., Gillmor, S. C., \& Rabinowicz, S. A. (2010). Complicating college students' conception of the American dream through community service learning. Michigan Journal of Community Service Learning, 17(1), 5-19.

Sharkey, P. (2013). Stuck in place: Urban neighborhoods and the end of progress toward racial equality. Chicago: University of Chicago Press.

Sharkey, P., \& Elwert, F. (2011). The legacy of disadvantage: Multigenerational neighborhood effects on cognitive ability. American Journal of Sociology, 116(6), 1934- 81.

Siemers, C. S., Harrison, B., Clayton, P. H., \& Stanley T. A. (2015). Emerging place as partner. Michigan Journal of Community Service Learning, 22(1), 101-104.

Silverman, R. M. (2005). Redlining in a majority black city?: Mortgage lending and the racial composition of Detroit neighborhoods. Western Journal of Black Studies, 29(1), 531.

Sugrue, T. J. (2014). The origins of the urban crisis: Race and inequality in postwar Detroit. Princeton, NJ: Princeton University Press.

Tach, L., Jacoby, S., Wiebe, D. J., Guerra, T., \& Richmond, T. S. (2016). The effect of microneighborhood conditions on adult educational attainment in a subsidized housing intervention. Housing Policy Debate 26(2), 380-397.
The Skillman Foundation. (n.d.) State of the Detroit child 2012 report. Detroit, MI: The Skillman Foundation.

Tinkler, B., Hannah, C., Tinkler, A., \& Miller, E. (2014). Analyzing a service-learning experience using a social justice lens. Teaching Education, 25(1), 82-98.

Vezzali, L., Stathi, S., Giovannini, D., Capozza, D., \& Trifiletti, E. (2015). The greatest magic of Harry Potter: Reducing prejudice. Journal of Applied Social Psychology, 45(2), 105-121.

Wade, R. C. (2000). Beyond charity: Service learning for social justice. Social Studies and the Young Learner, 12(4), 6-9.

We the People of Detroit Research Collaborative (2016). Mapping the water crisis: The dismantling of AfricanAmerican neighborhoods in Detroit. Detroit, MI: We the People of Detroit.

Wilson, W. J. (2012). The truly disadvantaged: The inner city, the underclass, and public policy. Chicago: University of Chicago Press.

Wodtke, G., Harding, D., \& Elwert, F. (2011). Neighborhood effects in

temporal perspective: The impact of long-term exposure to concentrated disadvantage on high school graduation. American Sociological Review 76,713-736.

\section{Author}

MARY-CATHERINE HARRISON (mc.harrison@udmercy.edu) is associate professor of English and co-director of the Honors Program at the University of Detroit Mercy, where she also serves as the executive director of Rx for Reading Detroit. Her research on Victorian literature, narrative theory, and the psychology of reading has appeared in Narrative, Poetics Today, Journal of Family Theory and Review, and the collection Rethinking Empathy through Literature. 